\title{
Evaluation of a psychosocial education program for families with congenital adrenal hyperplasia
}

\author{
I Mitchelhill ${ }^{1 *}$, G Betts $^{1}$, J King ${ }^{2}$, F Murray ${ }^{3}$, J Crisp ${ }^{4}$, C Briggs $^{4}$ \\ From 7th APPES Biennial Scientific Meeting \\ Nusa Dua, Bali. 14-17 November 2012
}

Congenital Adrenal Hyperplasia (CAH) is an inherited condition caused by an enzyme deficiency which leads to a potentially life threatening adrenal crisis. Poor compliance and any illness, injury, or major medical procedure can be life threatening. Medical interventions, counselling and timely education are essential for these families.

This study evaluated a psychosocial education program (PEP) developed to meet the needs of families with a child with $\mathrm{CAH}$, with the additional opportunity of exploring the impact of $\mathrm{CAH}$ on the child and family.

Two hundred and two participants (parents/carers/ children with $\mathrm{CAH}$ and siblings), from 68 families took part in the study. Participants attended a full-day workshop which included information about $\mathrm{CAH}$, a practical injection session, group discussions and provision of a resource folder. Data were collected to explore the impact of CAH on the child and family using the Child Behaviour Checklist (CBCL) and the Child Health Questionnaire (CHQ). Sibling data were collected for comparison of the $\mathrm{CAH}$ group with siblings and population norms. Evaluation of the PEP involved baseline and follow-up (immediate, six months and 12 months post education) measures of knowledge using the CAH Knowledge Assessment Questionnaire (CAHKAQ) and a formal evaluation.

Evaluation of the PEP showed that knowledge increased immediately following the PEP, which was maintained over time. Sick day management was seen to be the major challenge for families. Fathers' and Mothers' scores for behaviour (CAH group compared to siblings) were within population norms, although Father's rated children with $\mathrm{CAH}$, having lower social competence than siblings and norms. Fathers' and Mothers' were in agreement about the impact of $\mathrm{CAH}$, with ratings lower than siblings and population norms for bodily pain \& discomfort, general health of the child, and emotional impact on parents. The PEP

'Endocrinology, Sydney Children's Hospital, RANDWICK, NSW, Australia Full list of author information is available at the end of the article achieved its major goal of increasing knowledge about $\mathrm{CAH}$, and was positively evaluated by families. The workshop has now been incorporated into a DVD that is available to families and health professionals.

\section{Authors' details}

'Endocrinology, Sydney Children's Hospital, RANDWICK, NSW, Australia. ${ }^{2}$ Sydney Nursing School, NSCCH, University of Sydney, Camperdown, NSW, Australia. ${ }^{3}$ Sydney Nursing School, University of Sydney, Camperdown, NSW, Australia. ${ }^{4}$ Faculty of Nursing Midwifery \& Health, University of Technology, Sydney, NSW, Australia.

Published: 3 October 2013

\section{doi:10.1186/1687-9856-2013-S1-P119}

Cite this article as: Mitchelhill et al:: Evaluation of a psychosocial education program for families with congenital adrenal hyperplasia. International Journal of Pediatric Endocrinology 2013 2013(Suppl 1):P119.

Submit your next manuscript to BioMed Central and take full advantage of:

- Convenient online submission

- Thorough peer review

- No space constraints or color figure charges

- Immediate publication on acceptance

- Inclusion in PubMed, CAS, Scopus and Google Scholar

- Research which is freely available for redistribution 